\title{
THE CONCEPT LIFE IN UKRAINIAN NATIONAL LINGUISTIC WORLDVIEW AS REPRESENTED BY UNIVERSAL IMAGES
}

\author{
РЕПРЕЗЕНТАЦІЯ КОНЦЕПТУ ЖИТТЯ В УКРАЇНСЬКІЙ НАЦІОНАЛЬНІЙ \\ МОВНІЙ КАРТИНІ СВІТУ УНІВЕРСАЛЬНИМИ ОБРАЗНИМИ КОМПОНЕНТАМИ
}

\author{
Bobro M.P. \\ orcid.org/0000-0003-4086-4607 \\ Candidate of Philological Sciences, \\ Associate Professor of the Department of General and Applied Linguistics \\ of V.N. Karazin Kharkiv National University
}

The article considers representation of the concept LIFE in Ukrainian national linguistic worldview by universal images. The analysis of Ukrainian lexemes and idioms taken from the relevant dictionaries of the Ukrainian language by continuous sampling method made it possible to single out the following universal images: movement, up - down, heart, soul, fire, water, somatisms, colour images and zoonyms. The study shows that movement is one of the most productive universals that has a great potential for expressing the image constituent of the analysed concept. Life conceptualization in Ukrainian national worldview is related to such movement aspects as its direction, trajectory (which determine close connection between the category of movement and the category of space) and intensity. The direction of movement defines the evaluative potential of the image: the oppositions "up - down", "right - left", "straight - crooked" are linguocultural universals that correlate with the evaluative opposition "good - bad" which is fundamental for people's world perception. The opposition "up - down" represents life in Ukrainian linguistic worldview not only through the image of movement but also through static staying up or down. The universals soul, heart as denoting life in Ukrainian linguoculture prove to be close in their semantics and often are synonymous. An important factor in life presentation by the images of fire and water is the quantity (for fire it concerns the heat discharged). Among somatisms, head has the closest connection with a person's biological life, physical state while hands, feet, neck and back are related to the kind of life when a person has to work hard and too much. The most important for colour conceptualisation of life is the white colour that correlates with light and actualises visual world perception. Zoonyms mostly represent a person's emotional states, primarily negative that are motivated by the conception of the chthonic world.

Key words: linguoculturology, linguistic worldview, concept, universal, life.

У статті розглянуто універсальні образи, що репрезентують концепт ЖИТТЯ в українській мовній картині світу. У результаті аналізу лексики та фразеології української мови, вилученої з відповідних словників методом суцільної вибірки, було визначено, що образ руху є однією з найбільш продуктивних універсалій, що має великий потенціал як маніфестант образного складника аналізованого концепту. Встановлено, що в українській національній картині світу концептуалізація життя пов'язана з такими аспектами руху, як напрям, траєкторія (що зумовлюють тісний зв'язок категорії руху з категорією простору) та інтенсивність. Напрям руху визначає оцінний потенціал цього образу: опозиції «верх - низ», «правий - лівий», «прямий - кривий» є лінгвокультурними універсаліями, що корелюють із базовою для світосприйняття людини оцінною опозицією «гарний - поганий». Опозиція «верх - низ» репрезентує життя в українській мовній картині світу не лише через образ руху, а й через образ статичного перебування наверху чи внизу. Універсалії душа, серце на позначення життя в українській лінгвокультурі виявляються близькими за змістом і часто виступають синонімічними. У репрезентації життя образами води і вогню важливим виявляється кількісний показник (для вогню кількість стосується виділеного тепла). Серед соматизмів найбільший зв'язок із біологічним життям, фрізичним станом людини, виявляють соматизми голова та меншою мірою ноги, тоді як руки, ноги, шия, спина пов'язані із способом життя, за якого людина надмірно працює. Колірна концептуалізація життя виявляє найбільший зв'язок з ахроматичним кольором білий, що є співставним із світлом і актуалізує візуальне сприйняттям світу. Зооніми найчастіше репрезентують емоційні стани людини, здебільшого негативні, що мотивуються, зокрема, уявленнями про хтонічний світ.

Ключові слова: лінгвокультурологія, мовна картина світу, концепт, універсалія, життя.

Studying the special features of reality representation in national worldviews is one of the leading trends of modern linguistic research. Among different approaches to the problem is the one dealing with concept studies. Concepts are mental units that accumulate the results of people's cognitive activity. Being a unit of consciousness, the concept is difficult to get direst access to, so scientist have to deal with linguistic material that represents concepts in a particular language. Words and idioms are among the linguistic units that give relevant information about the concept they represent. By their lexical meaning, words that name the concept give a definite idea of the concept's main features while idioms give wider information concerning the ethno-specific features of reality perception by the people who speak the given language.

The concept LIFE is a universal, as it is hard to imagine a culture, which would not have the idea 
of life and the relevant linguistic means of expressing it. "Universals ideally are generalizations that capture properties $\langle\ldots\rangle$ that are essential to and stable across all possible languages" [24, p. 1]. Linguocultural universals are fundamental human concepts that form a common conceptual basis for the development of different cultures, their thinking and languages [27]. At the same time, different nations, different cultures have some specific features of life perception. "The universal and the culture-specific is reflected in the language as a system, which, when analized, makes a certain worldview... The cultural-linguistic specifics and the cultural-linguistic universals are not incompatible and do not counteract. They coexist" $[11$, p. 86].

The concept LIFE in national worldviews has been studied on the data of various languages: Ukrainian, English, German, Russian, Chinese and others. The structure of the concept has been determined; the mythological ideas that form the basis of some cultural connotations have been established; the poetic images that describe life and the metaphoric representation of the concept have been analyzed $[4 ; 10]$. The studies of the concept LIFE in Ukrainian linguoculture are mainly based on phraseology or paroemias. The particular research aspects include Ukrainian national stereotypes and their correlation within the social, temporal and existential theme classes [5]; the ideographic structure of the concept, its associative complex and connection with microconcepts like soul, fate and others [9]; the archetypes and gestalts that reflect life perception [1]; the anthropocentric character of the concept [12].

However, life is such a broad, all-encompassing phenomenon that there still are aspects that have not been fully studied. Universal image components as representing the concept LIFE in Ukrainian linguoculture have not as yet become the object of linguistic studies. Including new material to the research also helps to reveal some data that has not as yet been paid attention to. The aim of the present article is to describe the features of the image representation of the concept LIFE by universal image components in linguistic worldview of Ukrainian people. The study is based on Ukrainian words and idioms (both mainly verbal) that represent human life.

The analysed material made it possible to single out the following universals that represent life in Ukrainian linguistic culture: movement, up - down, heart, soul, water and fire, somatic components, colour images and zoonyms. All of them can be found in different cultures as the image components representing various concepts. Yet, in every culture the particular verbal and cultural realisation of such representa- tion can have some special features. For example, the colour scheme can have some differences as well as the significance of a particular colour.

The idea of life as movement is not new. "To live means to constantly move forward" [2]. Movement is a universal concept, which can be found in various cultures. "Really, there is nothing as familiar and inherent to us as movement, which is the main property, the main sign of life - whether in philosophic, semiotic, historic etc. as well as in the ordinary "experienced-by-man" sense" [6, p. 6].

In Ukrainian linguoculture the idea is expressed by the verbs of movement like ходити, бігати, which can be used about people with the meaning "to be alive, to stay alive, to be in good health" (see also the idioms with the same meaning no землі ходити; по світі ходити) or about life itself (життя біжить; життя йде; життя тягнеться). Occasional comparisons with non-related cultures make it possible to find some similarities and differences in their world perception. For example, movement metaphors about life are used both in Ukrainian and English cultures: ...життя біжсить дуже швидко, і ніколи людині зупинитися на хвилину; Життя йде далі.; ...людське життя тягнеться надто довго для одного кохання...; The Government recognises that rural life goes in cycles, with ups and downs; My life runs much more smoothly. The same applies to the use motion verbs about people to denote the state of health (Miй did ще бігає, як бравий козак; My father ... is $85 \ldots$ He still walks, pretty slowly, and we take him off shore), while their use to denote the state of being alive looks like more common for Ukrainian national worldview (Чоловік мій Федір ще шкандибає, а дідові Оникієві вже не шкандибати, иарство йому небесне).

Walking is a typical movement type that represents life in Ukrainian worldview. The verb ходити and its derivatives become components of numerous idioms denoting various aspects of human life, such as age, wealth or poverty, social position, family life and others: входити в літа; ходити босим; ходити y передовій; ходити по бабах; ходить як під обухом; ходити по лезу бритви, під Богом ходити. The intensity of walking can be different and depends on the age of the person. Slower movement characterizes older people and is represented by verbs like шкандибати, лазити, while fast movement is characteristic of children and young people: бizamu, швендяти; see also молодість летить вільною пташкою, а старість лазить черепашкою. However, when we speak about life, not people, the situation is just the opposite: in childhood, life 
(time, years) goes very slowly and is described by verbs such as тягнутися. Later the intensity grows (verbs like проходити) and the older the person becomes, the faster life moves on - it runs or even flies by (verbs like бігти, летіти).

Movement intensity is an important factor in the image representation of life. Besides describing the physical state of human beings, it also denotes a specific way of a person's life - very busy, devoid of rest. The idea is expressed by verbs such as ганяти, бігати, мотатися that denote fast, intensive and mostly chaotic movement: ганяе мов неприкаяний; бігає як скажений; мотається як худе иуиеня.

The idea of busy life, full of constant work can be expressed not only by the intensity of movement but also by its direction. The circular movement commonly means infinite, endless movement, as the circle is a universal sing for infinity [21, p. 32]. In sign language used by the deaf community, for example, repeated circular movement means "an activity which lasts a long time or a continuing situation" [26, p. 346]. As concerns busy, restless life in Ukrainian liguoculture, it is represented by the idea of movement in circles with the verbs like крутитися, вертітися: крутиться як білка в колесі; вертиться як чорт у боклазі; крутиться як муха в окропі. On the other hand, the same idea can be manifested by verbs denoting constant, endless vertical chaotic repeated movement: повчеться як чорт у попелі; товчеться як галка на гнізді; товчеться як у ступі.

Movement direction suggests the interconnection of two universal concepts: movement and space. "The division of space into passed and not yet passed is impossible without movement, and movement itself cannot be understood without such space division" [6, p. 8]. Besides the already considered horizontal circular movement, there are also "left-right" movement and space images. Here, the idea of movement is closely related to the image of way (шлях, дорога). "The notions movement and way are universal and functionally significant for reconstruction of any model of the world" [16, p. 5].

The "left-right" paradigm in representing life can be traced in such idioms as стоятина неправильному шляху; повернути на путь праведних; стояти на правильній дорозі; стати на правильну путь; ходити наліво. As seen from the examples, here the idea of space location becomes secondary, giving way to the evaluative potential of the relevant space designators: right is good, left is bad [20]. According to D. Casasanto, it is body-specific representation of good and bad. In his paper, it is argued that such universal world perception is related to a certain "lopsidedness" of human body: most people have a dominant hand it is usually the right one. Therefore, they "interact with their environment more fluently on one side of body-centered space than the other" $[18$, p. 353]. The idea is proved by some experiments, showing that left-handers are more likely to associate left with something positive than right-handers. On the other hand, the general "right - good, left - bad" idea represented by linguistic means is perceived as correct by both right- and left-handers, for it is part of the linguistic worldview as it is given to them [18].

Related to the "left-right" paradigm is the universal "straight-crooked" paradigm as a manifestation of the same "right-bad" or "norm-antinorm" oppositions. "It is ... apparent in the etymologies of the words in various languages for "right" and "left": right is often derived from a root meaning "straight", while left is often associated with "crooked" [23, p. 79]. In Ukrainian, idioms with the components прямий (рівний) and кривий denote, respectively, the right and wrong way of life: по кривому иляху поїхав; круті повороти; зійти з прямої дороги. The idea of crookedness can also be express by verbs and nouns denoting the corresponding movement direction or trajectory: збочувати зі иляху; давати гаку.

Another space-related universal image is the opposition up - down. According to G. Lakoff, this spatial metaphor, like the others described above, is related to our body functioning [20]. However, the "good-bad" associations of this one, unlike the "right-left" perception for the right-handed and the left-handed, remains stable [18]. Up is always good, down is always bad. In Slavic culture, up symbolises wellbeing, fertility, liveliness, wealth, while down is associated with deficiency, death. Accordingly, the movement up and more often down represents changes in health (вставати з ліжка; занепадати; здо́ляти (dialect); спустетися (dialect), the last three meaning "to be very ill"), wealth (піднятися; вставати на ноги; пропадати; niдупадати; приопасти (dialect), meaning accordingly "to become wealthy", "to become poor"), person's social position (птах високого польоту; скотитися вниз), emotions (упадати meaning "to grieve", повісити голову), freedom or subjugation (вставати з колін; схиляти голову).

Very important "up-down" correlations are "up - God, Heaven" and "down - the underworld". The former is present in static metaphors designating a person's emotional state, which unlike dynamic "up-down" metaphors are mainly positive: раювати; не чути землі під собою; добре, як у небі; перебувати на сьомому небі. It can also be 
traced in the idioms denoting the kind of life when a person has to work too much: не мати коли на небо глянути; і вгору глянути ніколи; не мати коли й угору глянути. Besides suggesting the body position - when a person works, the head usually looks down at the work - the above idioms represent the action of looking up as praying, communicating with God. A similar idea can be found in English: “... he had so much business to do on earth, that he had no time to look up to heaven".

The universal images of heart and soul are also quite productive in the image representation of the concept LIFE. Though these two are quite different - heart is a physical object while soul is immaterial and cannot be seen of felt - they are very close to each other due to their direct connection with life. As for heart, this connection is quite straightforward: heart is the body organ, which is essentially important for the body's staying alive. With soul it is not as explicit, but can be revealed through etymology. In case of the Ukrainian word дyma, the connection with life is based on the notion of breathing: the lexeme duхати is still used in modern Ukrainian with the meaning "to live". In English, for example, the verb breath also means "to be alive", but the lexeme soul is thought to be related to the Greek psyche ( $\left.\psi v \chi \eta^{\prime}\right)$ - "life, spirit, consciousness" [22].

Another indicator of the "heart-soul" connection in Ukrainian linguoculture is the interchangeability or synonymy of the lexemes душа, серue in idioms describing person's various emotional states: легко на душі/сериі; відпочити серием/душею; душа/серие болить; душа/серие тремтить. This interchangeability is especially significant when the action named by the verb is directly inherent for only one of them. For example, physical damage is normal for heart as a physical organ but can hardly be expected for something immaterial like soul. However, in Ukrainian we find the following: душа/серие розривається навпіл; кривавиться серие/душа; душа/серие рветься на дві половинки. The same metaphors are not much characteristic of English.

Fire and water are two of the basic elements and they can be both life-giving and ruinous. In Ukrainian national worldview the idea of the duality of fire is based on the amount heat is gives, which shows through the gradation hot - warm - cold, with warm representing the norm: згоріти; ледь живий та теплий. The same semantics motivates the way people's material position is described (холод та голод; гріти руки "get money") as well as laziness (працює як кіт на печі) or way of living (як на вулкані жити; варитися в котлі). The idea of the life-giving heat in Ukrainian linguoculture is peculiarly realised through the image of stove (niy) as a symbol of mother principle, native home, the continuity of life: лежати на печі, сидіти в запічку. The image of water as representing biological life is positively connotated, simbolising health and physical strength, recovery after illness: pосте як з води; $я к з$ води вийшов. Negative social and emotional aspects of living are represented in relation to exceeding the quantity norm, when water correlates with alcohol, blood, sweat, tears: $n^{\prime} \epsilon$ як воду, кров ріками тече, проливати піт; обливатися сльозами. As regards sweat and tears, the English language, in contrast, accentuates the fact rather than big quantity (for example, sweat "to work hard" is much more common than drop or shed sweat).

Somatisms, such as head, hands, feet, back and others, represent biological and social life aspects, personal characteristics and emotions of people. The head is universally associated with biological life aspects (being alive): голова циіла на плечах, зложити голову. Idioms with the components руки and ноги, which are the most mobile, active body organs, describe a person's health: насилу ноги носять; рука не піднімасться; на ногах ("in good health"). In English, the same idea is associated with legs/feet: be on your last legs; be back on one's feet.

The idea of hard, exhausting work in a person's life is expressed in Ukrainian linguistic worldview through the idea of physical damage to such body parts as navel (nуn), tends (жили), hands (руки) or bending the prototypically straight body parts (neck, back, backbone): надривати пупа; рвати жили; рвати руки; гнути хребет; гнути шию як віл у ярмі. In the English linguistic worldview, the idea of work can also occasionally be represented by idioms with somatic components, but it is mainly hands, and there they describe the process of work rather than its intensity and difficulty. The material position of a person is expressed by means of the somatisms throat (горло), and stomach (живіт) through their connection with food: наїдати черево; горлом пхає; з горла лізе; аж з горла пре. The same idea is represented in English, but with the help of the somatism mouth (live from hand to mouth).

World perception through colour and zoonyms metaphors is a universal phenomenon, but the colour scheme and the animalistic images can significantly differ from culture to culture. The dominant colour-based image denoting life in Ukrainian linguoculture is the image білий свim that means "life in all its forms and manifestations". White colour here represents the fundamental universal opposition "light - dark" that is based on man's visual per- 
ception of the world around. The English equivalent of the Ukrainian білии свim - the wide world - is related to size, accentuating the openness, unlimitedness of the world. That idea is also expressed in the Ukrainian idioms світ білий замкнувся, but the visual aspect appears paramount. In such visual world perception, characteristic of Ukrainians, the images "white"/"light" are related to the ability to see the world around, which occurs as a very important factor. It being impossible to see the life and the outside world is a key motivator of the figurative representation of suffering, negative emotions, poor health: не бачити світу білого (meaning "to suffer, feel unhappy"); світ білий крутиться перед очима (meaning "to feel bad"), на білий світ би не дивився (meaning "to lose the will to live because of grief and unhappiness").

Language units with animalistic components conceptualise mostly social life aspects and a person's emotional state. They are obviously marked axiologically, the positive or negative evaluation being connected to the cultural connotations of the rel- evant animal. For example, such animals as snake, toad, mouse, crow are associated with the chthonic world: ворон ловити, гадюка ссе коло серия. Their localisation close to a person's heart also actualises the opposition "warm - cold" that correlates with "life - death" opposition. The metaphoric representation of a person's emotional state is related to the image of bird in an open or closed space: жити як вільна пташка, битися наче птах у клітиі.

Thus, the analysed universal images proved quite productive in representing the concept LIFE in Ukrainian national linguistic worldview. The comparisons with the English worldview showed that the more abstract and wide universals like movement, up - down are similar in their presentation of the analysed concept in the two worldviews, while somatisms, colour images and zoonyms are more likely to be specific in their realisation in a particular culture. Including data from other linguocultures to the research will make it possible to find out more about the universal and culture-specific features of national worldviews.

\section{REFERENCES:}

1. Близнюк О.О. Концепти «життя» $\mathrm{i}$ «смерть»: лінгвокультурологічний аспект (на матеріалі паремійного фонду української та італійської мов) : автореф. дис. ... канд. філол. наук: спец. 10.02.17. Київ, 2008. 20 с.

2. Владзімірський М. Афоризми. URL : http://aphorism.org.ua/subrazd.php?page=1\&pages_block=1\&rid= $4 \&$ sid $=265$.

3. Грущак О.M. Метафоричне представлення концепту LIFE в англомовній афористиці. Молодий вчений. 2017. № 4.3 (44.3). С. $62-65$.

4. Демидкина Е.А. Фразеологизмы, паремии и афоризмы как средство объективации концепта "Leben" в немецкой языковой картине мира : дис. ... канд. фрилол. Наук : 10.02.04. Саратов, 2007. 264 с.

5. Іванова І.Б. Фразеосемантичне поле «життя/смерть»: національні стереотипи та їх кореляції : автореф. дис. ... канд. фрілол. наук : спец. 10.02.01. Київ, 2008. 19 с.

6. Концепт движения в языке и культуре. Москва : Издательство «Индрик», 1996. 384 с.

7. Корпус текстів української мови. URL: http://www.mova.info/corpus.aspx\#.

8. Корпус української мови. URL: http://korpus.org.ual.

9. Краснобаєва-Чорна Ж.В. Концепт ЖИТТЯ в українській фрраземіці : дис. ... канд. фрілол. наук : 10.02.01. Донецьк, 2007. 463 с.

10. Лі Джіанпінг. Концепти «життя» та «смерть» в російській мові : автореф. дис. ... канд. фрілол. наук : 10.02.02. Харків, 2009. 15 с.

11. Ніколенко А.Г. Етнокультурна сутність мовної свідомості і культурні концепти як френомен лінгвокультури. Науковий вісник кафедри ЮНЕСКО КНЛУ. Серія Філологія. Педагогіка. Психологія. 2013. Вип. 27. C. 82-88.

12. Саєвич І.Г. Антропоцентричний вимір концепту ЖИтТЯ. Науковий часопис Національного педагогічного університету ім. М.П. Драгоманова. Серія 10. «Проблеми граматики і лексикології української мови». 2015. Вип. 12. С. 67-72.

13. Словник української мови. В 11 томах. Т. 1-11. Київ : Наукова думка, 1970-1980.

14. Фразеологічний словник української мови / Редкол. (голова) Паламарчук Л.С. Кн. 1-2. Київ : Наукова думка, 1993.

15. Франко І. Галицько-руські народні приповідки. Зібрав, упорядкував і пояснив Др. Іван Франко. Том I-III. Етнографрічний збірник. Том X, XVI, XXIII, XXVII, XXVIII. Львів : Друкарня Наукового товариства імені Шевченка, 1901-1910.

16. Цивьян Т.В.: ДВИЖЕНИЕ и ПУТЬ в балканской модели мира. Исследование по структуре текста. Москва : Индрик, 1999. 376 с.

17. Юрченко О.С., Івченко А.О. Словник стійких народних порівнянь. Харків : Видавнича група «Основа», 1993. $175 \mathrm{c}$. 
18. Casasanto D. Embodiment of abstract concepts: good and bad in right- and left-handers. Journal of Experimental Psychology: General. 2009, Vol. 138, No. 3. P. 351-367.

19. English corpus. URL: https://www.english-corpora.org/iweb/.

20. Lakoff G., Johnson M. Metaphors we live by. Chicago, London : The University of Chicago Press, 1980. $242 p$.

21. Lima M. The Book of Circles: Visualizing Spheres of Knowledge. New-York : Princeton Architectural press. 2017. $272 \mathrm{p}$.

22. New world encyclopedia. URL: https://www.newworldencyclopedia.org/entry/Soul.

23. Seuren P. From Whorf to Montague: Explorations in the Theory of Language. New York : Oxford University Press, 2013. $418 \mathrm{p}$.

24. Siemund P. Linguistic universals and language variation. Berlin/New York : DE GRUYTER MOUTON, 2011. $472 \mathrm{p}$.

25. The free dictionary. URL: https://idioms.thefreedictionary.com/.

26. Tobin Y. A semiotic approach to compare and contrast signed versus spoken language. Psycholinguistics: scientific and technological challenges. Porto Alegre, 2010. P. 341-349.

27. Wierzbicka A. Understanding cultures through their key words. Oxford. New York : Oxford University Press, 1997. $317 \mathrm{p}$.

УДК 811.161.2'373-112:2

DOI https://doi.org/10.32782/tps2663-4880/2020.13-1.3

\title{
«ВИСОТА» У СТАРОУКРАЇНСЬКІЙ МОВНІЙ КАРТИНІ СВІТУ “ВИСОТА” IN OLD UKRAINIAN LINGUISTIC WORLDVIEW
}

\author{
Бутко С.Г., \\ orcid.org/0000-0002-4778-2914 \\ кандидат філологічних наук, \\ старший викладач кафедри украӥнської мови \\ Харківського національного університету імені В.Н. Каразіна
}

Статтю присвячено вивченню структурно-семантичних і функційних особливостей одиниць лексико-словотвірного гнізда зі стрижневим словом «високий». Вербальні репрезентанти зазначеної характеристики в різних дискурсах набувають специфічних семантичних і функційних властивостей, що зумовлені суспільно-політичними, історичними, релігійними та іншими чинниками.

Джерелом дослідження $є$ «Словник української мови XVI - першої половини XVII століть». Залучений до аналізу матеріал, що містить головним чином книжну лексику різнодискурсивної належності, з огляду на морфемну будову поділено на прості однокореневі слова та складні слова-композити.

Важливою детермінантою, що зумовлює семантичні властивості лексико-словотвірного гнізда, є релігійна свідомість, що вплинула на формування змістових параметрів фрагмента мовної картини світу, об'єднавчим елементом якого $€$ «висота». Богоцентричність виявляється у значній кількості лексем із коренем вис- (виш-) на позначення Бога.

Орієнтованість писемних текстів на релігійний дискурс зумовлює кореляцію семантики лексеми «висота» з біблійною картиною світу, в основі якої лежать християнські уявлення про два світи - людський та божественний, земний і небесний, нижній і верхній. Це засвідчує і зафріксована в словнику відповідна фразеологія, що увиразнює паралельність, ізоморфність цих двох світів.

Прикметники з компонентом висок- на позначення фрізичних характеристик людини є маркерами вертикальної моделі світу, а сам прикметник «високий» може характеризувати простір, кількість, виражати духовно-релігійні або морально-етичні поняття, набуваючи в певних контекстах позитивно-оцінних або негативно-оцінних конотацій. Тісний взаємозв'язок формально-граматичної структури і світоглядно-концептуальної семантики демонструють дієслова з коренем вис-. Композити з компонентами висок- і висоц- виявляють дискурсивну маркованість, що засвідчує вживання лексем у контекстах різної жанрово-стилістичної належності.

Ключові слова: висота, високий, релігійна картина світу, староукраїнська мовна картина світу, історична лексикологія.

The article presents a study of the structural-semantic and functional features of the units of the derivational family with the core word "високий" (vysokyi, "high"). In different discourses, the verbal representatives of the above characteristic acquire specific semantic and functional properties which are determined by social and political, historic, religious and other factors. 